\title{
Evaluation of the Thyroid Status and Types of Thyroid Dysfunction in Beta-Thalassemia Major Patients More Than 9 Years of Age in Wassit, Iraq 2020
}

\author{
Ahmed I. Ansaf ${ }^{1}$, Safa Faraj ${ }^{1 *}$ (D), Hussien A. Abdul-Azziz ${ }^{2}$ \\ ${ }^{1}$ Department of Pediatrics, College of Medicine, Wasit University, Al Kut, Wasit, Iraq; ${ }^{2}$ Department of Pediatrics, Al-Kut Materntiy \\ and Child Hospital, Kut, Iraq
}

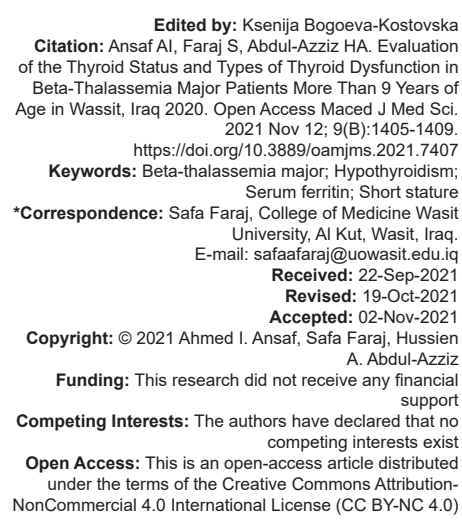

Introduction

The prevalence of Beta Thalassemia Major (BTM) in Iraq is increasing every day, due to high consanguinity marriage with the absence of premarital screen by hemoglobin $(\mathrm{Hb})$ electrophoresis to prevent this lifelong disease with multisystem complications.

This heavily affects the health system as they need lifelong treatment with blood transfusion with expensive chelation therapy to control iron overload in addition to regular monitoring for bone, heart, liver, kidney, brain, and endocrine functions.

The poor compliance for treatment had a great influence on increasing iron overload and its precipitation on different important organs such as the liver, heart, and endocrine organs.

Still patients with Beta-Thalassemia Major suffer from many unrecognized and poorly estimated endocrine complications causing a huge additional mental and physical sequences.
The frequency of hypothyroidism (HT) in Thalassemia patients ranges from 6 to $30 \%$ among different countries [1]. In many studies, they show that the lower iron overload markedly decrease HT prevalence and it seems that the prognosis depends on the amount and the duration of iron overload [2], [3].

In spite of The improvement in the survival rate happened after offering regular blood transfusion with oral and subcutaneous iron chelation treatment for all BTM patients; the frequency of endocrine including $\mathrm{HT}$, hypogonadism, Diabetes Mellitus (DM), hypoparathyroidism have increased in long-term survivors [3], [4], [5].

The needs for assessing, early treatment, and identifying the precipitating factors for HT in BTM are important for this lifelong disease.

Thyroid dysfunction could be primary, i.e.,: The damage in the thyroid gland, central i.e: the pituitary gland or hypothalamus is damaged and the secretion of thyroid-stimulating hormone (TSH) is inhibited, and subclinical: when thyroxine levels are within 
normal reference but serum TSH levels are mildly elevated [6], [7]

The sequences of HT may lead to many cardiovascular events such as impairment of contraction and relaxation of heart ventricles, decrease heart rate, and increase peripheral vascular resistance. All these, eventually lead to a decrease in cardiac output.

The subclinical HT which usually the most common type, usually affects brain function, development and can cause memory impairment [3], [8].

\section{Patients and Methods}

This is a cross-sectional study that was performed on 66 patients with BTM having more than 9 years old randomly selected in Al-Kut Hereditary Blood Disease Center at Wassit province in the south of Iraq. Data collected from patient's files after taking written permission from the center and patients or their parents. This study is done from March to August 2020. The information were collected from patients file including sex, age, height, weight, type of chelation therapy, frequency of transfusion compliance for treatment presence of other diseases such as DM, Hepatitis B virus, hepatitis $C$ virus, and amenorrhea were evaluated.

Mean $\mathrm{Hb}$ level for the last 12 months, serum ferritin level, Thyroid function were (TSH, T3, T4) was measured by enzyme-linked immunosorbent assay through VIDAS machine in the lab of Al-Kut Hereditary Blood Disease Center.

Thyroid function was evaluated depending of standards of kits used in VIDAS:

Grades of HT have been identified as $(1,3)$ :

[1]. Primary HT (high TSH, low T4).

[2]. Subclinical HT (high TSH, normal T4).

[3]. Central HT (low or normal TSH, low T4).

Statistical analysis done SPSS 24 software with $p<0.05$ regarded as significant.

The correlations between Ferritin and the age of the studied patients, ferritin, and thyroxine (T4) level, Age with thyroxine (T4) were evaluated by Pearson Correlation.

Standard Deviation and Mean were used for Age, ferritin, T4, T3, TSH, and $\mathrm{Hb}$ level.

\section{Results}

The demographic data of sixty-six patients who enrolled in this study are shown in Tables 1 and 2,
Table 1: Descriptive data of the studied patients

\begin{tabular}{lll}
\hline Item & No. & Percentage \\
\hline Gender & 32 & \\
$\quad$ Male & 34 & 48.5 \\
$\quad$ Female & & 51.5 \\
Age group & 13 & 19.7 \\
$\quad$ I15 & 53 & 80.3 \\
$\quad$ More than 15 year & & \\
Iron chelator & 40 & 60.6 \\
$\quad$ Deferasirox (X-jade) & 26 & 39.4 \\
$\quad$ Deferoxamine (Desferal) & & \\
Iron chelator compliance & 40 & 60.6 \\
$\quad$ Good compliance & 26 & 39.4 \\
$\quad$ Poor compliance & & 34.8 \\
Stature for age & 23 & 65.2 \\
$\quad$ Normal & 43 & 21.2 \\
$\quad$ Below normal & & 78.8 \\
$\quad$ Ferritin level & 14 & \\
$\quad$ Mqual or below $2500 \mathrm{ng} / \mathrm{ml}$ & 52 & $\mathrm{nore} \mathrm{than} \mathrm{2500} \mathrm{ng} / \mathrm{ml}$
\end{tabular}

thirty-two of the patients were male $(48.5 \%)$, and thirtyfour of them were female $(51.5 \%)$, male-to-female ratio 0.9:1.

Table 2: Descriptive measurements data of the studied patients

\begin{tabular}{llllll}
\hline Item & $\mathrm{N}$ & Minimum & Maximum & Mean & SD \\
\hline Age/year & 66 & 13 & 36 & 18.86 & 4.6 \\
Mean Hb g/dl & 66 & 6.2000 & 10.0 & 8.5 & 0.7 \\
Serum ferritin (mean) $\mathrm{ng} / \mathrm{ml}$ & 66 & 716 & 12300 & 5485.12 & 3260.0 \\
TSH mlU/ml & 66 & 0.1200 & 60.0 & 11.06 & 17.16 \\
T4 mmol/L & 66 & 8.4 & 146.0 & 76.152 & 26.9 \\
T3 mmol/L & 66 & 0.3100 & 4.8 & 2.0 & 0.8 \\
\hline TSH: Thyroid-stimulating hormone, Hb: Hemoglobin. & & &
\end{tabular}

The mean age of the patients was 18.8 years, more than $80 \%$ of the patients more than 15 years of age.

All of the patients were treated with iron chelation therapy. Forty patients $(60.6 \%)$ of them were treated with Deferasirox (X-jade), 26 patients (39.4\%) on Deferoxamine (Desferal), more than 60\% of the patients were reported as proper iron chelator compliance. The height of 43 patients (65.2\%) in the studied sample was below the normal for their age, while 23 patients $(34.8 \%)$ had average height.

$14(21.2 \%)$ patients had serum ferritin below $2500 \mathrm{ng} / \mathrm{ml} .52$ (78.8\%) patients had serum ferritin equal to or more than $2500 \mathrm{ng} / \mathrm{ml}$; the mean serum ferritin was $5485.12 \mathrm{ng} / \mathrm{dl}$.

The mean $\mathrm{Hb}$ level was $8.5 \pm 0.7 \mathrm{~g} / \mathrm{dl}(6.20$ $10.0 \mathrm{~g} / \mathrm{dl})$. The mean serum level of TSH was $11.06 \mathrm{mIU} /$ $\mathrm{ml}$ with range (0.1200-60.0). The range of the T4 level was between $8.4-146.0 \mathrm{mmol} / \mathrm{L}$, and the mean level was (76.152 $\mathrm{mmol} / \mathrm{L})$. The range level of T3 was between $3100-4.8$, and, the mean level was $2.0 \mathrm{mmol} / \mathrm{L}$.

Table 3 and Figure 1 shows thyroid status of the patients, HT status was detected in 31 patients, and their percentage was $47 \%$ from 66 patients, and they classified into three groups: 16 patients with subclinical HT $(24.2 \%)$, eight patients with central HT (12.1\%), seven patients with primary HT $(10.6 \%)$. The normal thyroid status was reported in $35(53.0 \%)$ of patients.

Table 3: Thyroid status of the studied patients

\begin{tabular}{lll}
\hline Item & Frequency & Percent \\
\hline Normal & 35 & 53.0 \\
Subclinical hypothyroidism & 16 & 24.2 \\
Central hypothyroidism & 8 & 12.1 \\
Primary hypothyroidism & 7 & 10.6 \\
Total & 66 & 100.0 \\
\hline
\end{tabular}




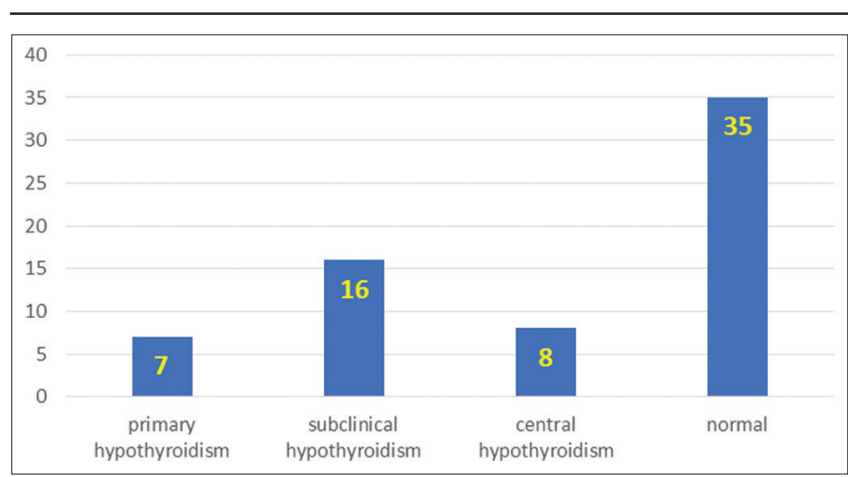

Figure 1: Thyroid status of the patients

Relation between thyroid status and many variables is shown in Table 4; there was a statistically significant correlation between thyroid status and the stature, $p=0.03$.

Table 4: Relation between thyroid status of thalassemia patients and other variables

\begin{tabular}{lllllll}
\hline Item & $\begin{array}{l}\text { Primary } \\
\text { HT }\end{array}$ & $\begin{array}{l}\text { Subclinical } \\
\text { HT }\end{array}$ & $\begin{array}{l}\text { Central } \\
\text { HT }\end{array}$ & Normal & Total & $\begin{array}{l}\text { p } \\
\text { value }\end{array}$ \\
\hline Age for stature & & & & & & \\
$\quad \quad$ Normal stature & $1(4.3)$ & $3(13)$ & $6(26.1)$ & $13(56.5)$ & $23(100)$ & 0.031 \\
$\quad$ Below normal & $6(14)$ & $13(30.2)$ & $2(4.7)$ & $22(51.2)$ & $43(100)$ & \\
$\quad \begin{array}{lllllll}\text { Serum ferritin } \\
\quad \text { Equal or below } 2500 \mathrm{ng} / \mathrm{ml} l\end{array}$ & $2(14.3)$ & $1(7.1)$ & $4(28.6)$ & $7(50)$ & $14(100)$ & 0.09 \\
$\quad$ More than $2500 \mathrm{ng} / \mathrm{ml}$ & $5(9.6)$ & $15(28.8)$ & $4(7.7)$ & $28(53.8)$ & $52(100)$ & \\
Age group & & & & & & \\
$\quad \leq 15$ & $2(15.4)$ & $3(23.1)$ & $1(7.7)$ & $7(53.8)$ & $13(100)$ & 0.89 \\
$\quad$ more than 15 year & $5(9.4)$ & $13(24.5)$ & $7(13.2)$ & $28(52.8)$ & $53(100)$ & \\
\hline HT: Hypothyroidism. & & & & & &
\end{tabular}

From 31 patients with $\mathrm{HT}$, twenty one $(67.74 \%)$ patients had stunted height or short stature, from them $13(41.9 \%)$ had subclinical HT.

Twenty-four patients (46.1\%) from fifty-two patients with serum ferritin more than $2500 \mathrm{ng} / \mathrm{dl}$ were reported to have HT despite no significant $p=0.09$.

Twenty-five (47.1\%) from 53 patients with age more than 15 years had HT but with no statistic significant between thyroid status and the age of the patients.

The correlation between the age of the patients and the serum thyroxine T4 level was inverse with $p=0.16$, Pearson correlation $(r)=-0.17$. As showed in Figure 2 (i.e: with increasing in age thyroxin level decrease).

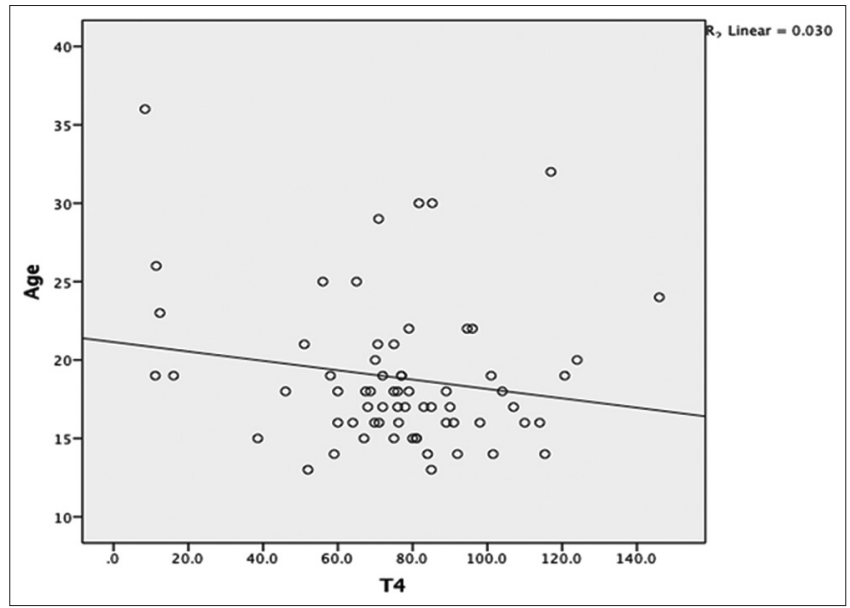

Figure 2: Correlation between age and T4 leve
The correlation between serum ferritin and serum T4 level was inverse with significant $p$-value, $p=0.0001$, Pearson correlation $(r)=-0.45$. As showed in Figure 3 (i.e.: with increasing serum ferritin thyroxin level decrease).

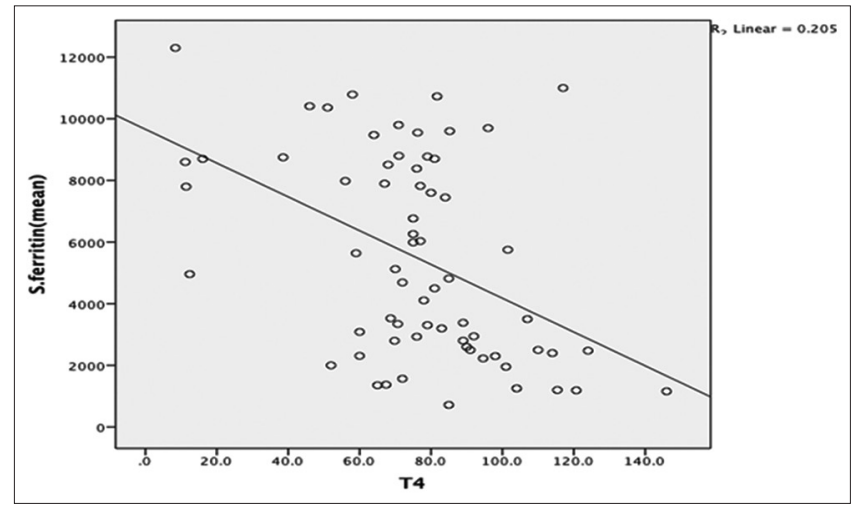

Figure 3: Correlation between serum ferritin and T4 level

\section{Discussion}

In this study there was high prevalence of HT $(46.96 \%)$ among the studied with BTM patients in Wassit province at south of Iraq.

This explanation for unpleasant results is start from absence of primary prevention for this horrible hereditary disease by doing mandatory $\mathrm{Hb}$ electrophoresis test for the couple who want to marry. The $\mathrm{Hb}$ electrophoresis machine available in the major Wasit province hospitals but not working because there is no maintenance and deficiency for kits needed for its functioning.

\section{Other local causes:}

1. Instability in maintenance, availability, and even quality for both chelating agents (Desferal and $\mathrm{X}$ - jade) that leads to iron precipitation on vital organs such as the heart, liver, brain, and endocrine organs.

2. Instability in maintenance in biochemical blood tests such as serum ferritin, thyroid function tests, that's needed to be done regularly for early detection which very useful for subclinical $\mathrm{HT}$ and required for follow-up after starting hormonal treatment.

3. In many patients, Poverty, low social class are important causes that lead to poor compliance for treatment and follow-up.

Overall, this may indicate a lack of attention with an absence of clear plan for primary prevention by government and health authorities about this inherited blood disease and its related issues and problems which can have lifelong multisystem sequences. 
In comparison with other studies, This prevalence was higher than a studies done by Rhman et al. (1) in 2019 in Pakistan, HT seen in (29.3\%) patients and by Soliman et al. in 2013 in Qatar (3) which had $(35 \%)$ had HT, Jehanzeb et al. study in 2016 in Pakistan with $(37.5 \%)$ have $\mathrm{HT},(14.6 \%)$ prevalence in Eshragi et al. study [9], [10].

In a review article done by Azami et al. in 2016, 574 patients had $23.3 \%$ overall prevalence [11].

In this study subclinical HT was the most common type (24.6\%), this less than Eshragi et al. [10], and Malik et al. study [12], in Pakistan which had (73.6\%), (94.44\%) respectively.

However, it is higher than in Soliman study was (6.3\%). Other studies done in Iran done for 1151 patients show overall prevalence of $6.7 \%$ for subclinical HT in Azami et al. review article [11].

The subclinical HT needs more attention for these patients with appropriate therapeutic measures to prevent converting subclinical to overt HT is essential. This include: More strict dose and adherence for iron chelation therapy, financial support, increasing patients and parents education courses, to increase awareness for these complications and its sequences, with regular biochemical and physical monitoring.

In this study (12.1\%) had central HT due to decreased secretion of TSH from the anterior pituitary gland or the hypothalamus and this was less than Soliman et al. [7], and Eshragi et al. studies which have $(76.4 \%)$ and $(15.7 \%)$ respectively central HT [10].

In this study primary HT detected in (10.6\%) of the studied patients which is similar to Eshragi et al. study (10.5\%) and less than Malik et al. [12], and Soliman [7], studies which both had $(5.8 \%)$ of primary $\mathrm{HT}$ and it is less than Azami et al. with $3.6 \%$ prevalence of primary $\mathrm{HT}$ [11].

In this study, there was a significant relation between short stature or height with HT $p=0.03$. From thirty-one patients with HT; Twenty one $(67.74 \%)$ patients had stunted height or short stature, from them $13(41.9 \%)$ had subclinical HT. This similar to Eshragi et al. study which shows significant relation between HT and Height $p(0.002)$ [10].

Strategy of Hypertransfusion with chelation therapy improves the expectancy of life, but the cost, difficulty in administration, and availability make iron or ferritin control is difficult [13].

In this study there was an inverse relation between serum ferritin and serum T4 level with significant $p$-value, $p=0.0001$; which means with increasing ferritin level the chance of finding low thyroxin level will be expected from iron overload infiltration into the thyroid glands with or without pituitary glands involvements, this goes with Malik et al. [12], and Jehanzeb et al. [9] studies. both found frequency of HT was associated with increased serum ferritin level but this does not go with Eshragi et al. study which found no significant relation between ferritin and HT p (0.584) [10].

In Soliman et al. study [7], found close to our study result through negative correlation between serum ferritin and FT4 $(r=-0.39, p=0.007)$.

Iron overload is the Major complication of thalassemia and is the most important concern for management [14].

In this study, the correlation between the age and serum T4 level was inverse relation but with insignificant $p=0.16$, Pearson correlation $(r)=-0.17$; which means with increasing age of patient with thalassemia Major the level of thyroxin likely to be low or decreased. Azami et al. [11], mention endocrine complications more common in the $2^{\text {nd }}$ decades of life in thalassemia Major patients and this close to Soliman study they found FT4 level show progressive decrease over the 12 years of age [7].

More studies are needed and larger sample of included patient to support and modify the possible causes or associated factors.

\section{Conclusions}

The prevalence of HT in thalassemia major patients in this study was high in Kut city south of Iraq. Authority planning for primary prevention and close supervision seems to be essential to minimize this inherited blood disease and its multi-system complications including the thyroid dysfunctions with high relation between $\mathrm{HT}$ with short stature and high ferritin level.

\section{References}

1. De Sanctis V, Roos M, Gasser T, Fortini M, Raiola G, Galati MC Impact of long-term iron chelation therapy on growth and endocrine functions in thalassaemia. $\mathrm{J}$ Pediatr Endocrinol Metab. 2006;19(4):471-80.

PMid:16759032

2. Borgna-Pignatti C, Cappellini MD, De Stefano $P, \mathrm{De}$ Vecchio GC, Forni GL, Gamberini MR, et al. Cardiac morbidity and mortality in deferoxamine-or deferiprone-treated patients with thalassemia major. Blood. 2006;107(9):3733-7. http://doi. org/10.1182/blood-2005-07-2933 PMid:16373663

3. Farmaki K. Hypothyroidism in thalassemia. In: Hypothyroidism Influences and Treatments. Vol. 1. Rijeka, Croatia: InTeach; 2012. p. 97-110.

4. Zekavat OR, Makarem AR, Haghpanah S, Karamizadeh Z, Javad $P$, Karimi M. Hypothyroidism in $\beta$-thalassemia intermedia Patients with and without hydroxyurea. Iran $J$ Med Sci. 2014;39(2):60-3. 
PMid:24453395

5. Abdel-Razek AR, Abdel-Salam A, El-Sonbaty MM, Youness ER. Study of thyroid function in Egyptian children with $\beta$-thalassemia major and $\beta$-thalassemia intermedia. J Egypt Public Health Assoc. 2013;88(3):148-52. http://doi.org/10.1097/01. EPX.0000436490.10201.28

PMid:24374948

6. Rehman H, Masood J, Sheikh S, Mehboob Q. Frequency of hypothyroidism in patients of beta thalassemia major. APMC. 2019;13(1):4-6.

7. Soliman AT, AI Yafei F, Al-Naimi L, Almarri N, Sabt A, Yassin M, et al. Longitudinal study on thyroid function in patients with thalassemia major: High incidence of central hypothyroidism by 18 years. Indian J Endocrinol Metab. 2013;17(6):1090-5. http:// doi.org/10.4103/2230-8210.122635

PMid:24381890

8. Bernal J. Thyroid Hormones in Brain Development and Function. In: Endotext. South Dartmouth, MA: MDText. Com, Inc.; 2015.

9. Jehanzeb K, Ahmad F, Lodhi MA, Ali S. Thyroid function assessment with B-thalassemia Major. Pak Armed Forces Med J. 2016;66(6):809-13.

10. Eshragi P, Tamaddoni A, Zarifi K, Mohammadhasani A Aminzadeh M. Thyroid function in major thalassemia patients: Is it related to height and chelation therapy? Caspian J Intern Med. 2011;2(1):189-93.

PMid:24024013

11. Azami M, Parizad N, Sayehmiri K. Prevalence of hypothyroidism, hypoparathyroidism and the frequency of regular chelation therapy in patients with thalassemia major in Iran: A systematic review and meta-analysis study. Iran J Ped Hematol Oncol. 2016;6:261-76.

12. Malik SA, Syed S, Ahmed N. Frequency of hypothyroidism in patients of betathalassemia. JPak MedAssoc. 2010;60(1):17-20. PMid:20055273

13. Rotaur I, Gaman A, Gaman G. Secondary haemochromatosis in a patient with thalassemia intermedia. Curr Health Sci J. 2014;40(1):67-70. http://doi.org/10.12865/CHSJ.40.01.13 PMid:24791210

14. Sharma S, Aggarwal R. Evaluation of thyroid hormones in Betathalassemic children of north India. UJMDS. 2014;2(1):39-42. 